\title{
Communication Networks as a Catalyst for Holistic Sustainability on Karst Landscapes
}

\author{
Elizabeth Willenbrink ${ }^{1, *}$, Leslie A. North ${ }^{2}$, Vu Thi Minh Nguyet $^{3}$, Jason Polk ${ }^{2}$ and James Graham ${ }^{4}$ \\ 1 The Parklands of Floyd's Fork, Louisville, KY 40245, USA \\ 2 Department of Earth, Environmental, and Atmospheric Sciences, Western Kentucky University, \\ Bowling Green, KY 42101, USA; Leslie.North@wku.edu (L.A.N.); Jason.Polk@wku.edu (J.P.) \\ 3 Institute of Geological Sciences, Vietnam Academy of Science and Technology, Hà Nội 100000, Vietnam; \\ vtmnguyet@igsvn.vast.vn \\ 4 Louisville Metro Government, Louisville, KY 40202, USA; james.graham@louisvilleky.gov \\ * Correspondence: ewillenbrink@21cparks.org
}

Citation: Willenbrink, E.; North, L.A.; Nguyet, V.T.M.; Polk, J.;

Graham, J. Communication Networks as a Catalyst for Holistic Sustainability on Karst Landscapes. Sustainability 2021, 13, 3360. https:// doi.org/10.3390/su13063360

Academic Editor:

Nicoletta Santangelo

Received: 11 February 2021

Accepted: 10 March 2021

Published: 18 March 2021

Publisher's Note: MDPI stays neutral with regard to jurisdictional claims in published maps and institutional affiliations.

Copyright: (c) 2021 by the authors. Licensee MDPI, Basel, Switzerland. This article is an open access article distributed under the terms and conditions of the Creative Commons Attribution (CC BY) license (https:// creativecommons.org/licenses/by/ $4.0 /)$.

\begin{abstract}
Equitable access to communication and education is a key aspect in ensuring sustainability in any natural area. Karst landscapes are especially susceptible to environmental degradation from natural and anthropogenic forces and can benefit from sustainable economic, social, and environmental practices. This study took place in Phong Nha-Kẻ Bàng National Park (PN-KB), a highly developed karst landscape in central Vietnam. Through in-depth interviews, this study explored the ways in which formal and informal communication networks between the diverse stakeholders living within the park can be used to better protect the landscape from further degradation. The research findings suggest that a lack of consistent communication between PN-KB's residents, rangers, and governing officials has left the landscape vulnerable to extensive degradation and susceptible to catastrophic climatic events. Increasing communication between the stakeholder groups within the park will bolster economic opportunity and ensure equitable access to information and resources, both of which will promote sustainable practices and karst landscape protection.
\end{abstract}

Keywords: karst management; agriculture; environmental education; Vietnam; Phong Nha-Kẻ Bàng

\section{Introduction}

Karst landscapes cover roughly $10-15 \%$ of the world's water-free surface, but the freshwater resources provided by these landscapes are a vital resource to $10 \%$ of the world's population. Freshwater aquifers located within karst landscapes are tapped for drinking water, residential uses, and agricultural irrigation [1-5]. Anthropogenic and environmental threats to these water resources are increasing as agricultural intensification, urbanization, and climate change accelerate [1,2]. Management and understanding of karst landscapes and their resources are often rudimentary, which increases likelihood of degradation [4,5]. Proper management and protection of karst landscapes requires equitable input and a holistic approach to protection by those living in the areas and those responsible for its management.

This study explores how sustainability on karst landscapes requires more than just traditional or narrowed environmental protection. Through the use of informal communication networks and stakeholder involvement, karst landscapes can be protected in a way that promotes environmental sustainability, while also protecting the social and economic livelihoods of people in the region. Sustainability has generally progressed towards a more holistic management approach, requiring buy-in from citizens, managers, and visitors [6,7]. With the karst landscape of Phong Nha-Kẻ Bàng National Park (PN-KB) serving as an example, we discuss here the need for education, engagement, and economic equity within communities living in vulnerable karst environments in order to best protect natural resources and human life. Sustainable practices in karst regions will prove to be increasingly 
important as water resources worldwide are threatened and the demand for clean, fresh groundwater increases [8].

The need for space to grow food has led to many people living and farming in landscapes that are vulnerable to degradation; arable land is becoming over-intensified and agriculture is being moved to areas less suitable for cultivation [8,9]. In some regions, the stress of agriculture directly conflicts with a country's natural geological terrain. The negative impacts that human and agricultural development have on karst landscapes is widely discussed in modern literature [1-3]. In karst regions with farming populations, there is increased soil tillage, soil erosion, and water contamination [1,10-12]. These effects can harm fragile karst ecosystems, both on the surface and within caves, and also pose a threat to the humans living on the landscape $[4,12]$. Generally, deforestation and agriculture on karst landscapes results in a loss of soil, decreased retention of nutrients, increased soil runoff, and unwanted sediments and contaminants entering already vulnerable water supplies. Karst soils are known for being highly erodible and rocky desertification is prevalent; with prolonged tillage, cropping, and harvesting [4]. Any substances on the surface, such as human, animal, or agricultural waste, can easily and quickly enter subsurface water supplies through soil leaching or sinkholes $[10,11,13]$. This pollution is minimally filtered by the limestone bedrock and, once it enters subsurface conduits, caves, or aquifers, it can cause widespread pollution. This is particularly important because populations living atop karst landscapes are often partially or fully reliant on groundwater for both personal and professional uses. Thus, increased pressure from agriculture, urbanization, and a reliance on fresh groundwater places humans living on karst landscapes and the landscapes themselves often at odds with one another [4].

As agricultural practices increase production, citizens in karst regions become more vulnerable to the effects of groundwater pollution, land erosion, and natural disasters $[4,14]$. In October 2020, the karst region of Central Vietnam was struck with historic monsoon rains leading to massive flooding of rivers and deadly landslides. As climate change progresses, the likelihood of catastrophic natural disasters increases [15]. Flooding on karst landscapes poses an enhanced threat due to both humans and then environment. Increased rain flow captures soil, sediments, and other surface pollutants, carrying them into both surface streams and the groundwater, increasing the likelihood of polluted and unsafe drinking water [16]. For people living in karst regions known for soluble bedrock and eroded soils, the risk of loss of property, livelihoods, and life are notable. Understanding of karst landscapes and how to live on them and protect them is vital as environmental pressures evolve.

The dangerous interactions of humans, climate, and karst landscapes are widely discussed among scientists and professionals, but oftentimes this information fails to make it to policymakers and citizens. This communication divide leaves large sections of a population with minimal knowledge of how and why they should change their behaviors, if at all [17]. If a farmer does not know that the pesticides being used are contaminating drinking water supplies, the farmer is unlikely to change their behaviors. Similarly, if a policymaker does not know that a nearby farm is contaminating their city's drinking water supplies, the policymaker is unlikely to pass legislation to protect from pollution. Obviously, individuals in direct contact with karst landscapes must first understand the processes going on beneath their feet before they are asked to change their behavior.

This study in PN-KB explored the ways in which informal communication can be used to emphasize understanding of strategies to protect karst landscapes and, therefore, successfully apply karst protection policies. While research has not been conducted on the agricultural social networks in communities atop karst landscapes, other research on social networks in Vietnamese agricultural communities shows that when individuals engage in informal discussions about important topics, they are more likely to understand those topics. A study by Hoang et al. (2006) in agricultural communities in Northern Vietnam also found that formal communication, such as classroom teaching or informational meetings, are a successful way to teach communities new scientific or policy information [18]. That 
article also outlined the ways in which agricultural communities utilize informal communication networks to spread important information on farming practices. Therefore, when it comes to educating broad populations and encouraging them to adopt new behaviors, both formal and informal communication should be used [18-20]. Informal communication strategies are particularly important within farming populations living within vulnerable environments, such as karst landscapes [18]. In addition, more communication between those living on the karst land and those in charge of managing the land fosters more trust between the two groups. Models in participatory planning in other regions in which humans are living in close contact with vulnerable geologic or biologic resources have shown that stakeholder involvement creates space for management solutions that best suit both humans and nature [21,22]. Allowing stakeholders a say in the management process becomes an effective way to protect the karst landscape that ensures a safe and healthy future for the vulnerable environment, while still meeting the economic and social needs of the residents in the area. Research by Hannah et al. (1998) also revealed that stakeholders may even recommend additional landscape and wildlife protection ideas that were not previously considered by management officials [21].

Surface and subsurface water flow is abundant in PN-KB, but a complete understanding of subsurface hydrology has not yet been achieved. Therefore, while it is known that water resources in PN-KB are likely being contaminated by urban and agricultural contaminants, there has been no widely published research on water quality or pollution in the park and there is little understanding of the geographic extent of this contamination [23]. However, the types of agriculture occurring in PN-KB, largely subsistence farming and wet rice cultivation, have been studied for their influence on karst resources. Lynagh and Urich (2002) studied these specific agricultural practices in a similarly populated protected karst region in the Philippines and found widespread soil degradation and water quality issues [24]. Knowing the subsurface groundwater networks of karst landscapes, it is likely that pollution threatens the entire human population, as well as the flora and fauna of PNKB. Thus, PN-KB residents, and any agricultural communities living atop karst landscapes, are both causing degradation to karst resources and feeling the negative consequences of this degradation [24].

\section{Materials and Methods}

This study focused on communication methods utilized by the agricultural community living within a protected karst area in PN-KB (Figure 1). PN-KB is located in the Quảng Bình province in north-central Vietnam and is predominantly underlain with karst terrain. A population of about 65,500 people live within the park, divided among 13 communes. PN-KB was incorporated as a UNESCO World Heritage Site in 2003 because of the region's extensive karst features and diverse flora and fauna. Karst features within the park include karst mountains measuring upwards of $1000 \mathrm{~m}$, sinkholes, and over 300 caves. The caves within PN-KB are well known throughout the world for their size; currently, the park contains the world's first and third largest caves by volume, Hang Son Doong and Hang En, respectively. PN-KB hosts roughly 10 million tourists per year who come to the area to visit show caves, such as Paradise Cave, and karst springs, such as Mooc Spring [23]. The park is a designated protected area consisting of a core zone of 123,326 hectares and a surrounding buffer zone of 221,344 hectares [25]. The core zone is divided into three areas: a strictly protected zone, an area for ecological restoration, and areas used for tourism and administration $[23,25]$. The PN-KB Management board employs 356 people, divided among administrative employees and park rangers [25]. 


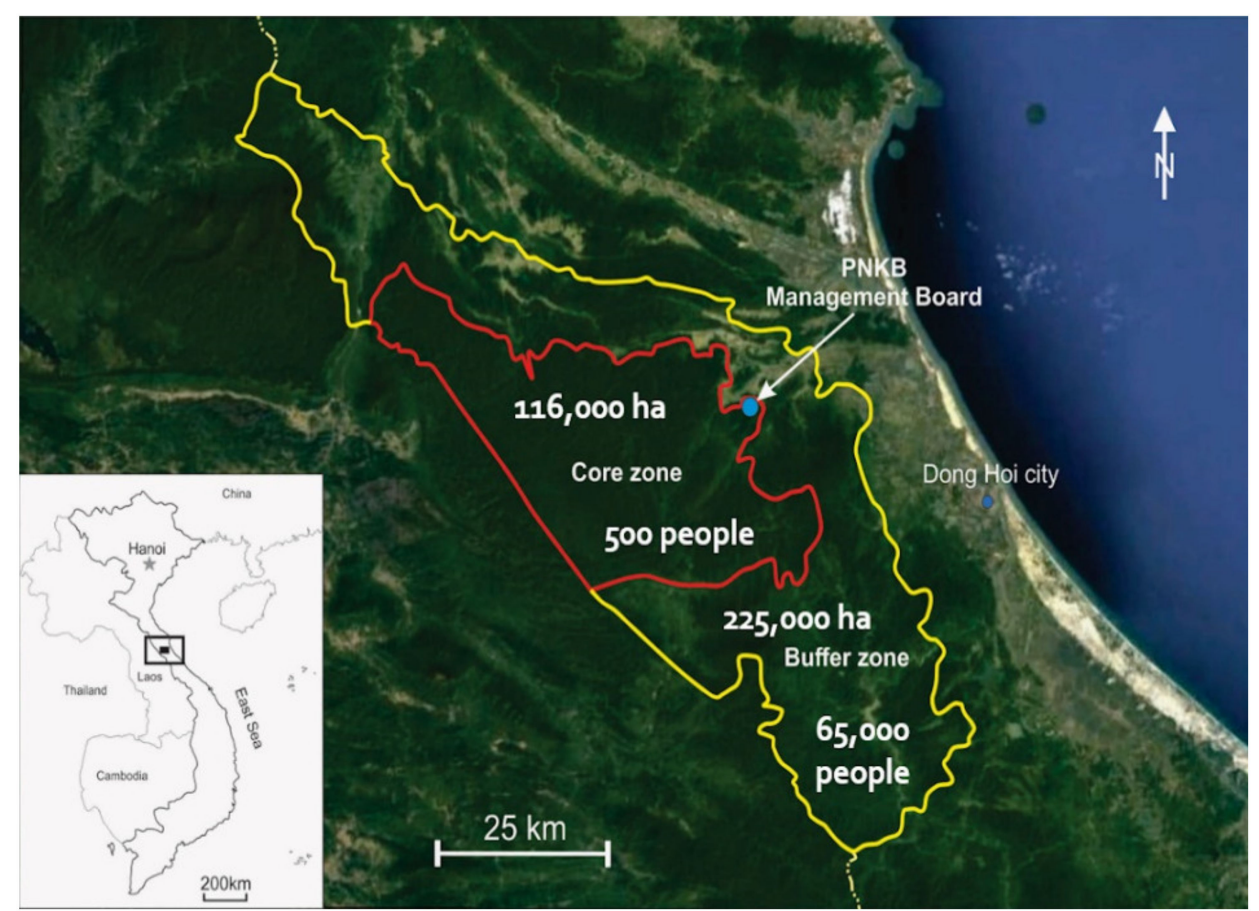

Figure 1. Map of Phong Nha-Kẻ Bàng National Park [26]. Image created by North et al. (2016) and used with permission from creators.

This study used a mixed-methods approach to explore the existing networks of communication between people living and working in PN-KB. Methods used included in-depth interviews, visual observations, and GPS location analysis. Overall, 68 interviews were conducted, of which six occurred with management officials, 12 with park rangers, and 50 with park residents. Interviewed park officials were responsible for outlining, financing, communicating, and enforcing the policies of PN-KB [23]. Rangers interviewed represented five ranger stations in both PN-KB's core zone and buffer zone. Finally, fifty residents were interviewed, broken down to 10 residents in five different buffer zone communities. Original plans included interviews at a sixth commune located in the core zone, but monsoon rains prevented access to that commune.

In-depth interviews lasted between fifteen minutes and an hour and a half. Interviews were semi-structured with a basic outline of topics and questions to be discussed and then time for general explanation and conversation about the farming and the landscape. General questions were asked about profession, frequency of communication with other people and groups in the area, and knowledge of karst landscapes and resources. At each interview location and in general communal areas, observations on physical location and communication methods were recorded. Additionally, GPS locations were logged for each interview location, the location of each commune office, and the location of the Management Board (Figure 2).

Interviews and observations were recorded, transcribed, coded, and initially analyzed using a content analysis model to extrapolate dominant themes. To identify themes, each interview was read three times and then compared to their larger group (residents, rangers, officials) to analyze the similarities between answers. Common answers among groups were compiled into a list based on topic and then answers were assigned with a broader theme. Statistical analysis was conducted on dominant themes to understand the frequency and distribution of answers based on interviewed groups. In this analysis, the frequency of each theme as mentioned in specific groups was used to identify the dominant communicative practices between and within groups. 
Interview Locations and Communication Hubs in Phong Nha-Kẻ Bàng National Park

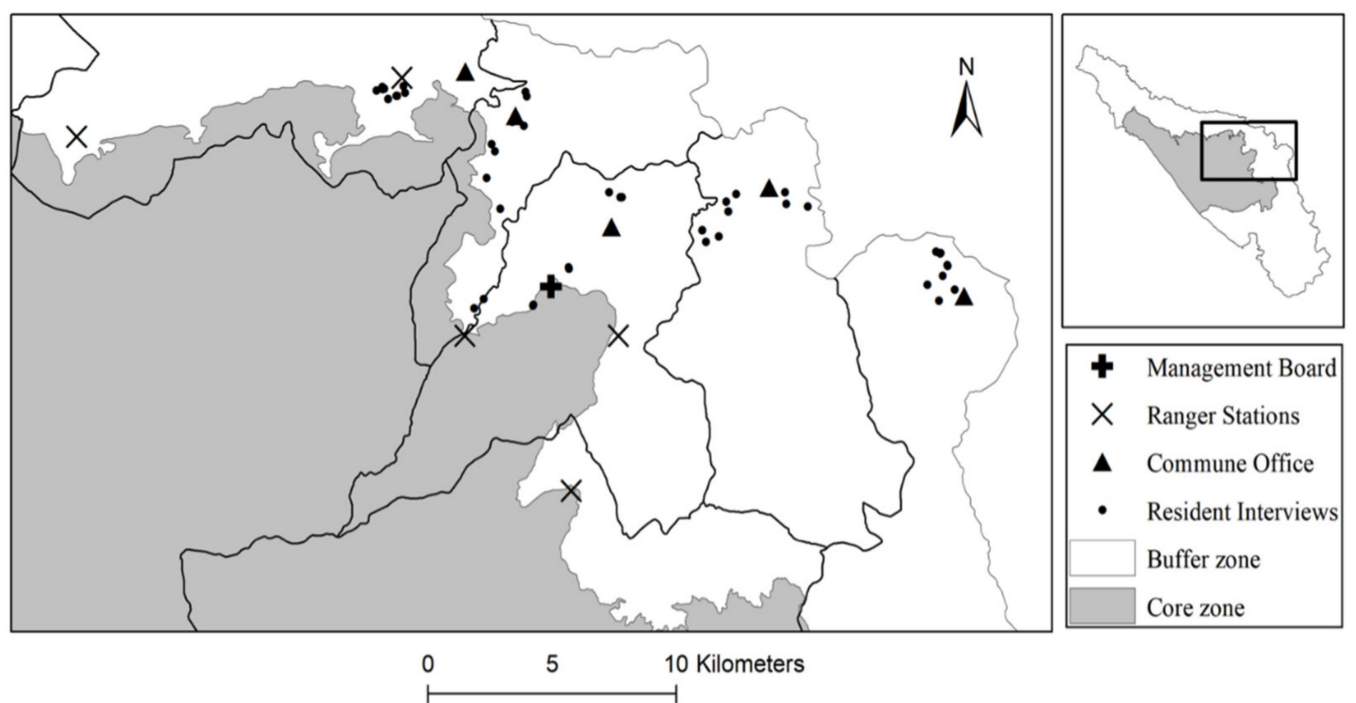

Figure 2. Interview locations and communication hubs in PN-KB (created by authors).

Once general themes for each group were identified and analyzed, a methods of agreement model was used to link dominant themes in terms of cause and effect [27]. To do this, themes were grouped based on if they were a cause, an effect, or both. The causes and effects were then organized in their relationship to other themes, which created a complex social system in which successes and failures in communication could be identified (Figure 3). Finally, maps were made using GPS locations to understand how space and distance were amplifiers and hindrances to communication between park officials, rangers, and residents.

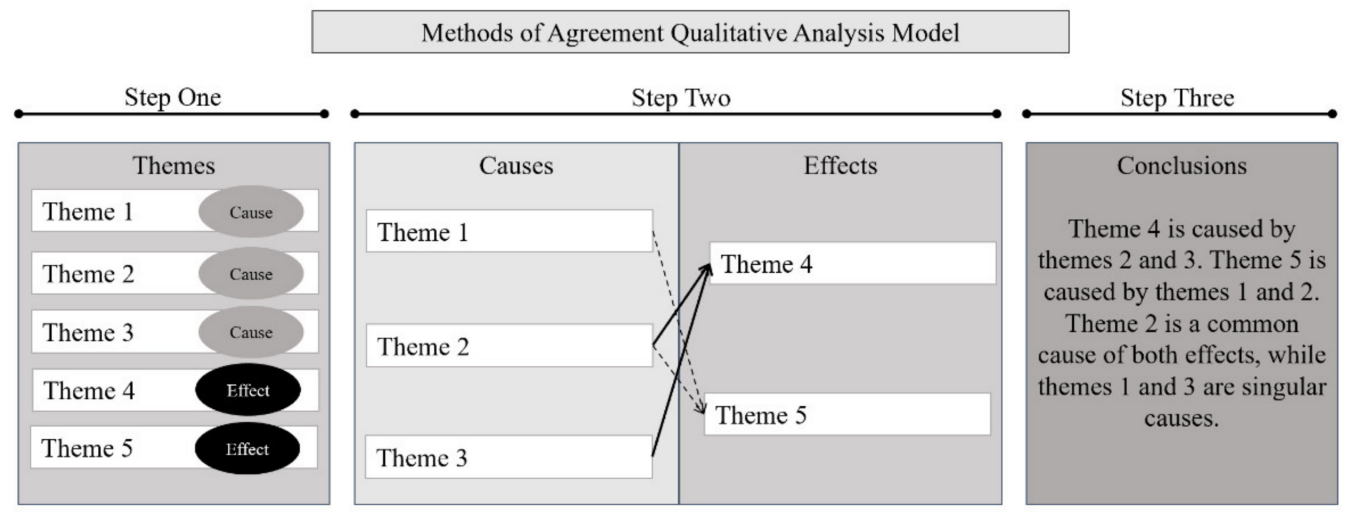

Figure 3. Methods of agreement qualitative analysis model [27] (created by authors).

\section{Results}

Dominant themes found during interviews and observation show that information flow between park officials in charge, park rangers who protect the land, and park residents who live on the land is minimal and often flows in a top-down hierarchy (Tables 1 and 2). Distribution of knowledge is often inequitable and relies on two factors: the amount of information held by the Management Board and the frequency of communication between the Management Board and other groups. Both of these aspects are limited, resulting in park rangers and residents who neither know about, nor understand, the karst landscape beneath their feet and its vulnerabilities. 
Table 1. Dominant themes among interviewed populations in Phong Nha-Kẻ Bàng National Park.

\begin{tabular}{cc}
\hline Population & Theme \\
\hline Frequent informal communication between residents. \\
Minimal understanding of karst landscapes. \\
Information flow through village meetings. \\
Minimal communication with park rangers and officials. \\
Mistrust and minimal communication with commune officials. \\
Job is forest protection and community education. \\
Preference for forest protection. \\
Trained predominately on forest protection. \\
Barriers to communication with residents. \\
Far distance from communities served. \\
Separation between core zone and buffer zone. \\
Limited communication with Management Board. \\
Minimal understanding of karst landscapes. \\
Agriculture has no effect on park protection. \\
Rangers \\
Minimal communication with rangers and residents. \\
Park mission as forest and biodiversity protection. \\
Shallow understanding of karst landscapes and resources. \\
Park-wide meetings as crux of communication. \\
Limited in-flow of scientific resources. \\
Social hierarchy. \\
Agriculture has minimal effect on park protection. \\
\hline
\end{tabular}

Table 2. Percentage of participants with categorical groups who discussed each dominant theme. The data are shown as a percent of total interviewees for each category whom discussed each theme.

\begin{tabular}{|c|c|c|c|}
\hline Topic & Residents & Rangers & Officials \\
\hline Communication with residents & 94 & 100 & 16.67 \\
\hline Communication with park officials & 18 & 66.67 & 83.33 \\
\hline Communication with commune officials & 14 & 16.67 & 83.33 \\
\hline Knowledge of karst landscapes and processes & 2 & 16.67 & 100 \\
\hline Knowledge of forest and biodiversity & 22 & 100 & 33.33 \\
\hline Agriculture as a threat to PN-KB & 0 & 0 & 0 \\
\hline Attendance at park-wide meetings & 0 & 0 & 83.33 \\
\hline
\end{tabular}

This study found that the PN-KB Management Board does not hold sufficient information on the PN-KB's landscape; therefore, if the managers do not have information, they cannot successfully communicate the topic to anyone else. Currently, the only two avenues in which residents are exposed to the karst landscape of PN-KB are through media and tourism, however, their breadth of knowledge is limited primarily to caves [28]. In particular, 42 out of 50 residents knew about the caves in the park through commercials for show caves and 22 had visited caves. Education about caves and karst landscapes is generally lacking in the tourism industry, largely due to the hands-off relationship between the PN-KB Management Board and tour companies. Moreover, most residents cannot afford admission costs for cave tours and they do not receive a discount [23,28]. 
The amount of karst science understood by PN-KB officials is higher than that of residents and rangers, due to their access to past research done in PN-KB. The park itself does not employ a karst scientist and consistent research on karst geology and water quality is not conducted by the board [23]. The PN-KB Management Board sometimes provides research information conducted by cavers who come to the area, but this information flow is inconsistent. Information about karst landscapes that is communicated among PN-KB officials is not always scientifically accurate. PN-KB officials understand the geology of the area and the solubility of limestone bedrock, but interviews suggest that they do not understand how the relationship between water and limestone can be affected by pollution in the area $[23,28]$. Any information on karst landscapes, correct or incorrect, is largely contained to the Management Board. Due to the lack of karst science being communicated among PN-KB officials, rangers, and residents, the population does not seem to understand their karst landscape and its vulnerabilities [23].

Channels of communication between PN-KB residents and employees are segmented and largely based on existing social and economic classes [28]. With the exception of one interviewed resident who was a retired government official, all interviewed residents were employed in working class agriculture and education sectors [23]. The data suggest that there are no efforts to communicate between social and economic groups unless those channels exist based on family or friendship [28]. The results from this study also suggest that communication between park officials and outside groups is minimal and, when it does occur, it is between a very selective group of recipients (Figure 4). For example, the Management Board is made up of seven units, but only one, the Head Rangers, reported consistent communication with local rangers and PB-KB residents. Therefore, only one seventh of the potential communicators within the Management Board are efficiently and consistently using their position to provide community education.

The results from this study indicate that residents value informal communication with and trust each other as information sources compared to park officials and rangers [28]. Interviews revealed that residents sought advice on management of their land and farms from their neighbors and their Head of Village, but only spoke about the landscape with regional or PN-KB officials when the officials told residents which crops to plant. Any informal or formal communication between residents and other groups, such as park officials and rangers, only occurred if a personal relationship existed between the resident and the park representative. Additionally, efforts for formal communication and education between park residents and employees were limited to educational programs for school children. Educational programs for adults do not occur [23]. Interviews also revealed there are no opportunities for park residents to visit and communicate with PN-KB officials.

Finally, the results from this study suggest that while land protection is the main priority for the PN-KB Management Board, continued unsustainable and illegal practices, such as illegal forestry and wildlife poaching, remain a challenge. There was no comprehension among officials and rangers that forestry and removal of biodiversity are closely intertwined with the general protection of a karst landscape as revealed through data analysis. 


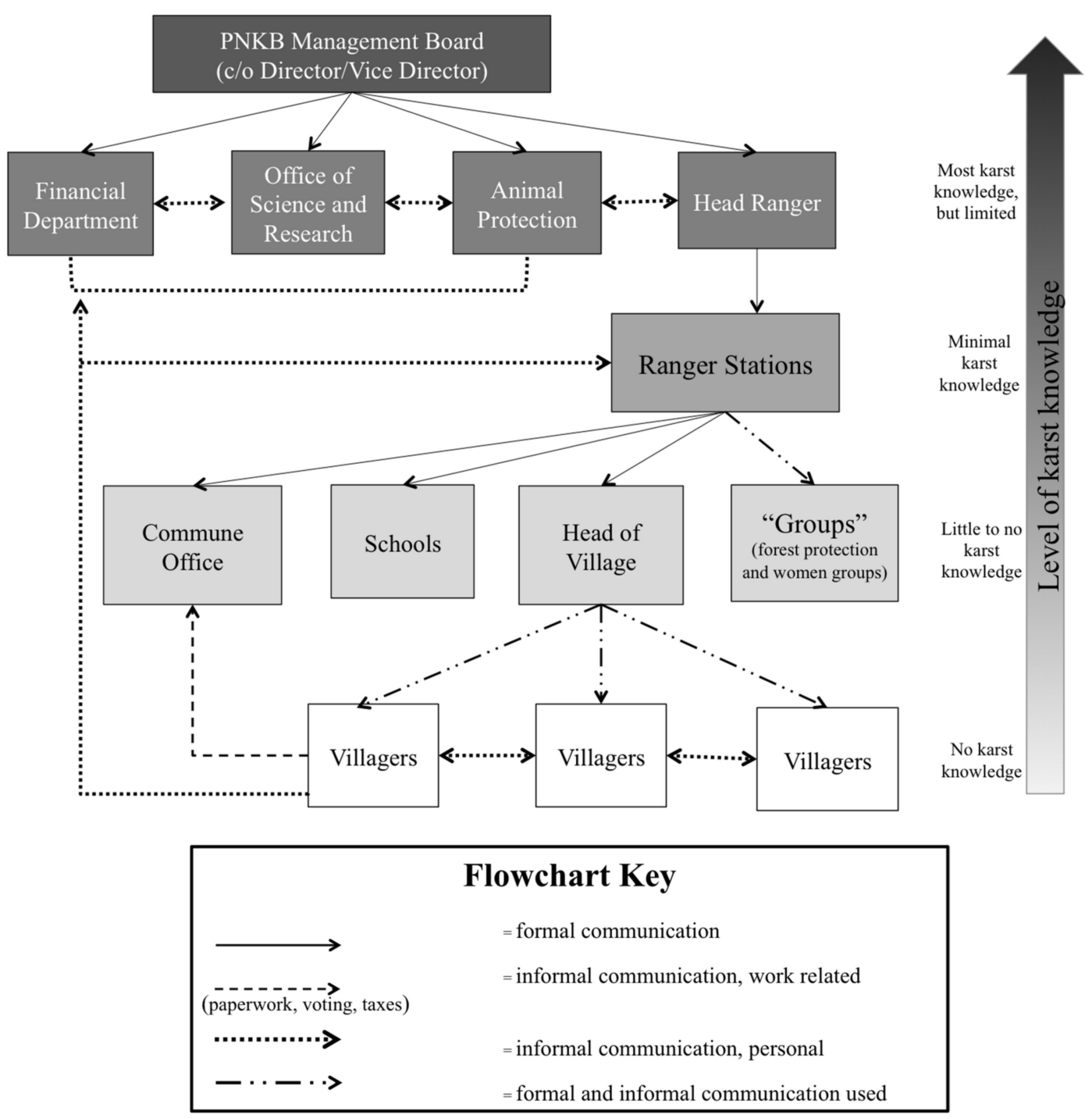

Figure 4. General communication flow and level of karst knowledge among populations living and working in Phong Nha-Kẻ Bàng National Park (created by authors).

\section{Discussion}

The idea of modern sustainability is rooted in the community. The idea of a healthy community is one in which all people, no matter the social class, have a standing and say in how that community is managed [21,22]. When all community stakeholders are involved in city and land management, economic opportunities are more likely to flow through the community and support all citizens. Moreover, when citizens who work on the land have a greater say in how that land is managed, it is more likely that policies will be drafted that support sustainable land use with both farmers and citizens in mind [6].

The results of this study in PN-KB revealed that when there is no open and trustworthy communication between the people living in a community and the people who manage the resources, both the vulnerable landscape and citizens living atop it are at risk of unsure futures [28]. The caves and karst landscape of PN-KB are popular tourist destinations for people from all over the world; however, if karst resources continue to go unprotected and communication between residents and park management is minimal, the long-term sustainability of the region's geologic and water resources is questionable [23,24]. For example, residents of PN-KB possess little understanding of how pollution atop karst landscapes quickly enters underground aquifers, which are then tapped for drinking water with little to no filtration. Moreover, none of the six management officials interviewed 
identified agricultural or human pollution as threats to the karst resources or described how contaminated karst water resources could cause issues for residents [23]. If animal and human waste continues to enter the groundwater, not only will residents suffer from pollution, but popular springs used for swimming in the park will not be able to safely function. In the case of PN-KB, this study suggests that a holistic approach to sustainability, focusing on social equity, economic opportunity, and environmental protection, will help protect the vulnerable karst landscape and improve the meaningful relationships between $\mathrm{PN}-\mathrm{KB}$ residents and officials.

While lack of communication networks among PN-KB residents and officials is a main issue, another hindrance to karst landscape protection is the lack of accurate scientific information coming into the Management Board. This research found that the PN-KB Management Board does not employ any scientist with specialties in karst landscapes and instead relies on old scientific information or new research provided to them by independent tourism companies to share their specific research at will. Since all new scientific information, particularly karst science, must go through the Management Board before it is dispersed among rangers and residents, if the Management Board lacks access to karst information, so does the broader population. For example, the director of PN-KB and other officials interviewed believed that the porous and permeable limestone bedrock filters out pollutants from water as it moves from the surface to subsurface. In reality, however, the opposite is true and limestone rock does not effectively filter pollutants $[1,4]$. This example of incorrect information has the potential to be communicated to other groups and could instill a sense that groundwater is drinkable when it is actually polluted with sediments, agricultural runoff, and human and animal waste.

Interviews for this study revealed that the area's residents expressed a deep sense of pride in their community and the natural landscape, as well as an understanding that their park sets standards because it is world famous; however, results from this study suggest this sense of pride is overshadowed by distrust for the officials and rangers in charge of management. Park residents often expressed that they had never communicated with PN-KB officials and many residents, especially those located in Commune 3, distrust park officials because of issues with financial corruption [23]. Interestingly, both park residents and officials possess unique knowledge of the natural landscape that would be useful to the other group, but the lack of communication means this information is never shared. For example, if the residents were to speak to PN-KB officials about how they live on, take care of, and farm on their land, this form of participatory planning would engender policies that embraced farming livelihoods, while also protecting soil and water resources [21,22]. Additionally, if PN-KB officials were to educate residents about the issues with soil erosion and water contamination, the residents would be able to practice safer agricultural practices that would yield crops while also protecting the land; however, as long as community involvement in park management does not exist in PN-KB, the issues of land degradation and water contamination will persist.

Education requires communication. Without trustworthy communication between those with information and those who need information, education will not exist [7,18,28]. This lapse in communication is exemplified in two directions at PN-KB: (1) park officials reluctant to communicate with residents in the area and (2) residents lacking an accessible avenue to communicate with park officials. For best protection of the karst landscapes, education needs to occur in both top-down and bottom-up directions. First, PN-KB officials lack an understanding of how the land functions for people who live and farm on the karst landscape. For example, farmers and residents interviewed for this project knew the contours of the land, how water flows, and where to retrieve groundwater. Many also struggle with land erosion that is common on karst landscapes. If residents are given a consistent avenue to communicate this information to park officials, the officials could learn more about how soil erosion and water runoff affect the people living on the land. By opening their doors to residents, both literally and figuratively, park officials could learn valuable information about the state of the land [21,22]. Second, by opening an avenue for 
bilateral communication between PN-KB officials and residents, there is a greater likelihood that scientific information about karst landscapes, soil erosion, and water quality could flow to residents and be reported to park officials as a management concern. Fostering bilateral communication between officials and residents would increase the trust that residents have in park officials, thus increasing community investment toward land protection. More investment and stakeholder involvement would also increase accountability for all people to treat natural resources in a way that protects both the humans on the land and the land itself $[21,22,28]$. Communication and education among people living and working in PN-KB will allow for a social equity dynamic under which all residents are given enough information to understand how to live atop a karst landscape in a way that promotes the long-term health of themselves and the land.

Economic sustainability is another vital resource in encouraging sustainability in a karst region. The residents of PN-KB interviewed for this study were largely low to middle class, but the majority of those interviewed could not afford to participate in any of the area's karst-based tourism. It was found that the only people who could afford to participate in the area's cave and karst tourism were the residents already working in the tourism sector. In PN-KB, informal education through show caves tours is an easy and accessible avenue for reaching a broad park population, but it is not currently utilized. Tourism, while it can have a tenuous relationship with scientific facts, is a useful resource to educate many people on the fundamentals of a karst landscape [17]. Therefore, residents without economic resources to engage in tourism are deprived of its educational benefits. In addition to the social inequities linked to PN-KB's tourism industry, there are also economic inequities. While many people living in the main urban center of PN-KB benefit from tourism through hostels, restaurants, and tour businesses, the extent of that economic benefit is minimal and benefits only a handful of people. None of the fifty interviewed residents had jobs that related to tourism and none identified economic benefits from the industry. One resident from the commune in which the majority of tourism occurs remarked that rangers and park officials do not bother talking to him because he "just farms" and is not engaged in tourism [29]. This study found that communities within the $\mathrm{PN}-\mathrm{KB}$ and surrounding the urban center are largely uninvolved in tourism and do not receive any economic benefits from visitors to the area. In fact, visitors may increase the burden on water resources and landscape degradation through their actions in the absence of integrated management [29].

In $\mathrm{PN}-\mathrm{KB}, 80 \%$ of residents rely on agriculture for their income and many more rely on their own subsistence farms for food [30]. When water and soil quality suffer due to issues unique to karst landscapes, the people who rely on farming may suffer as well. Thus, the health and livelihoods of people living and working within PN-KB rely on the environmental sustainability of the region's karst landscape and resources Due to the underground network of caves and fractures characteristic of karst landscapes, changes in one area of the environment of $\mathrm{PN}-\mathrm{KB}$, be it biological or geological, can have widespread implications for people who work and live there [1-3]; however, environmental sustainability in the region is impossible without a change to the social and economic structure of the area's management. Minimal communication between the people in charge of managing the area's karst water and geological resources and the people dependent on the resources results in unhealthy water quality, soil erosion, and susceptibility to natural disasters for everyone in the area.

Overarching social, economic, and environmental sustainability in PN-KB is increasingly important as climate change alters the patterns of natural disasters. The widespread flooding that occurred during the 2020 monsoon season in Central Vietnam exemplifies the natural vulnerabilities of karst landscapes. With rapid runoff and degraded soils, flooding in karst regions can also threaten landslides and catastrophic runoff, both of which can cause injury, loss of land and income, and even death among PN-KB residents [1-5]. As this region faces increased environmental pressures, the need for communication between $\mathrm{PN}-\mathrm{KB}$ officials and residents is necessary to the life and health of everyone in the area. 


\section{Conclusions}

Altogether, holistic sustainability in a region depends on environmental protection, social equity, and economic opportunity; this is particularly true in interconnected karst landscapes. These three pillars of sustainability depend on open and honest communication among all stakeholders in the region since everyone whose life or income is based in a region deserves a say in the policies that directly impact their land and life [7]. In PN-KB, the stakeholders are residents living within the national park, employees of the national park including officials and rangers, tourists visiting the area, and general government employees living and working in PN-KB. The PN-KB Management Board can use the findings of this study to implement an effective informal communication strategy for communicating to farmers about the sensitivities of karst landscapes to degradation and the policies implemented to address these sensitivities. Although this study focuses on Vietnam as a case study site, shortcomings in policy implementation, due to ineffective education and communication, are a common occurrence in many karst regions where agriculture is prevalent.

To achieve environmental protection in $\mathrm{PN}-\mathrm{KB}$, all aspects of the karst landscape must be understood and protected. Currently, decisions are based primarily on the environmental protection of the park, but even this is concentrated on forestry and biodiversity with little focus on the area's geologic and water resources. The first step toward better environmental protection is to encourage research of karst resources within the park and then to share such results with PN-KB staff and the general population of the area. It is only when people understand the interconnectedness of the surface and subsurface in karst landscapes that they will be able to make informed decisions about how to live and work with such vulnerable water and soil resources [1]. With all groups possessing the same knowledge about karst landscapes, residents and employees will be able to collaborate in ways that protect karst resources, while preserving the health and livelihoods of area residents.

The solutions suggested herein provide options that are relatively easy and inexpensive to implement. While it is not realistic to change the larger hierarchies within Vietnamese society, the social and economic equity of people living and working in PN-KB can be ameliorated through accessible communication networks $[7,28]$. Allowing stakeholder involvement in the management of PN-KB will allow park residents to speak up for their needs. Stakeholders feel the effects of landscape and environmental degradation, and their involvement is more likely to steer management to solutions that protect landscape and, therefore, protect local livelihoods. Stakeholder involvement can be achieved through monthly or quarterly meetings in which representatives from the PN-KB Management Board, local government officials, and elected representatives of communities within $\mathrm{PN}-\mathrm{KB}$ meet to discuss the social, economic, and environmental resources of the area.

Individual behaviors in karst landscapes can have widespread consequences; therefore, comprehensive, collective action is necessary for karst landscape protection. Such actions require healthy, consistent, and trustworthy relationships between those crafting policies and those living in the area carrying out and being governed by those policies. Phong NhaKẻ Bàng National Park is just one small karst region, but its current and future management sets an example for karst land management around the world. Many karst landscapes are threatened by human behaviors or incomplete management, thus setting an example of holistic sustainability in PN-KB can act as a catalyst for the adoption of meaningful land management in other karst regions. Overall, sustainable land management on karst landscapes is necessary for the future of humans because of our reliance on the fresh and clean groundwater contained within karst landscapes. Without clear communication and a complete understanding and adoption of karst protection policies by governments and citizens alike, vulnerabilities will continue to exist regarding access to clean drinking water and sustainable livelihoods in karst regions. 
Author Contributions: Conceptualization, E.W. and L.A.N.; Data curation, E.W. and L.A.N.; Formal analysis, E.W.; Funding acquisition, E.W., L.A.N., V.T.M.N. and J.P.; Investigation, E.W.; Methodology, E.W.; Project administration, L.A.N., V.T.M.N. and J.P.; Resources, L.A.N., V.T.M.N. and J.P.; Supervision, L.A.N., V.T.M.N. and J.P.; Visualization, J.G.; Writing—original draft, E.W.; Writing-review and editing, L.A.N., V.T.M.N., J.P. and J.G. All authors have read and agreed to the published version of the manuscript.

Funding: This research received funding from Western Kentucky University Graduate School, the Cave Conservancy Foundation, the WKU Applied Research and Technology Program, and the WKU ALIVE Center.

Institutional Review Board Statement: The study was conducted according to the guidelines of the Declaration of Helsinki, and approved by the Institutional Review Board of Western Kentucky University (protocol code 1060548-2, 4/26/2017).

Informed Consent Statement: Informed consent was obtained from all subjects involved in the study.

Data Availability Statement: Not applicable.

Conflicts of Interest: The authors declare no conflict of interest.

\section{References}

1. Ford, D.; Williams, P. Karst Hydrogeology and Geomorphology; John Wiley \& Sons Ltd.: West Sussex, UK, 2007.

2. Stevanović, Z. Karst waters in potable water supply: A global scale overview. Environ. Earth Sci. 2019, 78, 662. [CrossRef]

3. Goldscheider, N.; Zhao, C.; Auler, A.; Bakalowicz, M.; Broda, S.; Drew, D.; Hartmann, J.; Jiang, G.; Moosdorf, N.; Stevanović, Z.; et al. Global distribution of carbonate rocks and karst water resources. Hydrol. J. 2020, 28, 1661-1677. [CrossRef]

4. Coxon, C. Agriculture and Karst. In Karst Management, 1st ed.; van Beynen, P., Ed.; Springer: Dordrecht, The Netherlands, 2007; pp. 103-138.

5. LaMoreaux, P.E.; Powell, W.J.; LeGrand, H.E. Environmental and Legal Aspects of Karst Areas. Environ. Geol. 1997, 29, 23-36. [CrossRef]

6. Barrett, C.B.; Grizzle, R.E. A Holistic Approach to Sustainability Based on Pluralistic Stewardship. Environ. Ethics 1999, 21, $23-42$. [CrossRef]

7. Barrett, C.B.; Brandon, K.; Gibson, C.; Gjertsen, H. Conserving Tropical Biodiveristy amid Weak Institutions. BioScience 2001, 51, 497-502. [CrossRef]

8. Dragoni, W.; Sukhija, B.S. Climate change and groundwater: A short review. Geol. Soc. Lond. Spec. Publ. 2008, 288, 1-12. [CrossRef]

9. The World Bank. Agriculture for Development; World Development Report; The World Bank: Washington, DC, USA, 2008. Available online: http:/ / siteresources.worldbank.org/INTWDR2008/Resources/WDR_00_book.pdf (accessed on 1 October 2016).

10. Drew, D.P. Accelerated Soil Erosion in a Karst Area: The Burren, West Ireland. J. Hydrol. 1983, 61, 113-124. [CrossRef]

11. Jiang, Y.; Wu, Y.; Groves, C.; Yuan, D.; Kambesis, P. Natural and Anthropogenic Factors Affecting the Groundwater Quality in the Nandon Karst Underground River System in Yunan, China. J. Contam. Hydrol. 2009, 109, 49-61. [CrossRef] [PubMed]

12. Ciglič, R.; Hrvatin, M.; Komac, B.; Perko, D. Karst as a Criterion for Defining Areas Less Suitable for Agriculture. Acta Geogr. Slov. 2012, 52, 62-82. [CrossRef]

13. Chen, R.; Bi, K. Correlation of Karst Agricultural Geo-Environment with Non-Karst Agricultural Geo-Environment with Respect to Nutritive Elements in Guizhou. Chin. J. Geochem. 2011, 30, 563-568. [CrossRef]

14. Leisher, C.; Brouwer, R.; Boucher, T.M.; Vogelij, R.; Bainbridge, W.R.; Sanjayan, M. Striking a Balance: Socioeconomic Development and Conservation in Grassland through Community-Based Zoning. PLoS ONE 2011, 6, e28807. [CrossRef] [PubMed]

15. United States Geological Survey. How Can Climate Change Affect Natural Disasters? Available online: https://www.usgs.gov/ faqs/how-can-climate-change-affect-natural-disasters-1?qt-news_science_products=0\#qt-news_science_products (accessed on 10 February 2021).

16. Mahler, B.J.; Lynch, F.L. Muddy waters: Temporal variation in sediment discharging from a karst spring. J. Hydrol. 1999, 214, 165-178. [CrossRef]

17. North, L.A. Informal Karst Education in the United States and Internationally. Ph.D. Thesis, University of Southern Florida, Tampa, FL, USA, 2011.

18. Hoang, L.A.; Castella, J.C.; Novosad, P. Social Networks and Information Access: Implications for Agricultural Extension in a Rice Farming Community in Northern Vietnam. Agric. Hum. Values 2006, 23, 513-527. [CrossRef]

19. Khatam, A.; Muhammad, S.; Naseem, S.; Yousuf, H.; Ashraf, I.; Zafarullah, K.; Kuharoo, A. Communication of Agricultural Information through Group Contact Methods in Pakistan. Pak. J. Agric. Res. 2013, 23, 245-253.

20. Wood, B.A.; Blair, H.T.; Gray, D.I.; Kemp, P.D.; Kenyon, P.R.; Morris, S.T.; Sewell, A.M. Agriculture Science in the Wild: A Social Network Analysis of Farmer Knowledge Exchange. PLoS ONE 2014, 9, e105203. [CrossRef] [PubMed] 
21. Hannah, L.; Rakotosamimanana, B.; Ganzhorn, J.; Mittermeier, R.A.; Olivieri, S.; Iyer, L.; Rajaobelina, S.; Hough, J.; Andriamialisoa, F.; Bowles, I.; et al. Participatory planning, scientific priorities, and landscape conservation in Madagascar. Environ. Conserv. 1998, 25, 30-36. [CrossRef]

22. Margles, S.W.; Masozera, M.; Rugyerinyange, L.; Kaplin, B.A. Participatory Planning: Using Swot-AHP Analysis in Buffer Zone Management Planning. J. Sustain. For. 2010, 29, 613-637. [CrossRef]

23. Willenbrink, E. Policy Communication and the Influence of Agricultural Communities on Karst Landscapes. A Case Study in Phong Nha-Kẻ Bàng National Park, Vietnam. Master's Thesis, Western Kentucky University, Bowling Green, KY, USA, 2018.

24. Urich, P.B.; Day, M.J.; Lynagh, F. Policy and Practice in karst Landscape Protection: Bohol: The Philippines. Geogr. J. 2001, 167, 305-323. [CrossRef]

25. Thanh, L.M. Operational Management Plan 2012-2020: Phong Nha-Kẻ Bàng National Park, World Heritage Site; Kreditanstalt für Wiederaufbau: Frankfurt am Main, Germany, 2012.

26. North, L.A.; Polk, J.S.; Nguyet, V.T.; Tuan, T.P.; Quang, N.M. Evaluating Human-Environmental Impacts to the Karst Landscape of Phong Nha-Kẻ Bàng National Park, Vietnam Using a Modified Karst Disturbance Index Methodology. In Proceedings of the 2016 Meeting of the Geological Society of America, Denver, CO, USA, 24-28 September 2016.

27. Neuman, W.L. (Ed.) Social Research Methods: Qualitative and Quantitative Approaches, 4th ed.; Pearson Education: Needham Heights, MA, USA, 2000.

28. Willenbrink, E.; North, L.; Nguyet, V.T.M. Untapped Potential: Agricultural Social Networks as the Future of Karst Science Communication in Phong Nha-Kẻ Bàng National Park, Vietnam. Focus Geogr. 2018, 61. [CrossRef]

29. Semler, K. Development of a Karst Tourism Management Index to Assess Tourism-Drive Degradation of Protected Karst Sites. Master's Thesis, Western Kentucky University, Bowling Green, KY, USA, 2019.

30. Tuyet, D. Characteristics of Karst Ecosystems in Vietnam and Their Vulnerability to Human Impact. Acta Geologica Sinica 2001, 75, 325-329. [CrossRef] 